\title{
The Implementation of a Filter Kalman Method Forecasting Rainfall Obtained through Model ARIMA in Jambi
}

\section{Implementasi Metode Filter Kalman dalam Memprediksi Curah Hujan yang Diperoleh melalui Model Arima di Kota Jambi}

\author{
Mellyani Aprilia \\ Universitas Jambi \\ Indonesia \\ mellyaniaprilia@gmail.com \\ Nayla Desviona \\ Institut Teknologi dan Bisnis Muhammadiyah Purbalingga \\ Indonesia \\ nayladesviona02@gmail.com
}

\begin{abstract}
In the last three years the climatic conditions in Jambi City have experienced erratic weather conditions. One way to predict rainfall is using the Kalman Filter approach. However, in this case, the Kalman Filter method is implemented on the forecasting results from ARIMA (Autoregressive Integrated Moving Average) because there has been rainfall measurement data from 2008 to 2017 at BMKG Muaro Jambi Climatology Station which is also a function of time and the existing pattern will be described with using Time Series Analysis. Time series data is data that has a time series of more than one year on one object or data collected from time to time on one object. ARIMA model will be used to predict the next data. Kalman filter is a model part of the state space (state space) that can be applied in forecasting models. The Kalman filter consists of a prediction stage and a correction stage. This method uses a recursive technique to integrate the latest observational data into the model to correct previous predictions and make further predictions. This study aims to determine the method of implementing the Kalman filter in predicting rainfall obtained through the ARIMA model in Jambi City. The results of the 2018 Jambi City rainfall study show that the best ARIMA model formed is the ARIMA model $(1,0,1)$. The Kalman Filter model obtains a MAPE value of $24.92 \%$ which indicates that the Kalman Filter has a fairly good predictive ability.

Keywords: rainfall, ARIMA, kalman filter
\end{abstract}

\begin{abstract}
Abstrak
Dalam tiga tahun terakhir kondisi iklim di Kota Jambi mengalami kondisi cuaca yang tak menentu. Salah satu cara memprediksi curah hujan dengan menggunakan pendekatan Filter Kalman. Namun dalam hal ini, metode Filter Kalman diimplementasikan pada hasil peramalan dari ARIMA (Autoregressive Integrated Moving Average) dikarenakan telah adanya data pengukuran curah hujan tahun 2008 sampai tahun 2017 di BMKG Stasiun Klimatologi Muaro Jambi yang juga merupakan fungsi waktu dan akan digambarkan pola yang ada dengan menggunakan Analisis Deret Waktu (Time Series). Data time series adalah data yang memiliki runtun waktu yang lebih dari satu tahun pada satu objek atau data yang dikumpulkan dari waktu ke waktu terhadap satu objek. Model ARIMA akan digunakan untuk meramalkan data selanjutnya. Filter Kalman adalah sebuah model bagian dari state space (ruang keadaan) yang dapat diterapkan dalam model peramalan. Filter Kalman terdiri dari tahap prediksi dan tahap koreksi. Metode ini menggunakan teknik rekursif untuk mengintegrasikan data pengamatan terbaru ke model untuk mengoreksi prediksi sebelumnya dan melakukan prediksi selanjutnya. Penelitian ini bertujuan untuk mengetahui implementasi metode filter kalman dalam memprediksi curah hujan yang diperoleh melalui model ARIMA di Kota Jambi. Hasil penelitian prediksi curah hujan Kota Jambi tahun 2018 menunjukkan bahwa model terbaik ARIMA yang terbentuk adalah model ARIMA $(1,0,1)$. Pada model Filter Kalman diperoleh nilai MAPE sebesar 24,92\% yang menunjukkan bahwa Filter Kalman mempunyai kemampuan prediksi yang cukup baik.
\end{abstract}

Kata kunci: curah hujan, ARIMA, filter kalman

\section{PENDAHULUAN}

Pendidikan merupakan ujung tombak dari kemajuan negara yang bersifat mutlak karena tidak bisa terlepas dari fungsinya yaitu memperbaiki kualitas dari Sumber Daya Manusia (SDM). Pemerintah mencoba untuk selalu memperbaiki pendidikan di Indonesia mulai dari tenaga 
pendidik, sarana prasarana, dan juga kurikulum yang digunakan. Hal tersebut dilakukan untuk memberikan perubahan yang lebih baik dan mendasar dari pendidikan yang ada dan berlangsung.

Maret 2020 merupakan awal pandemi Covid 19 memberikan perubahan gaya hidup masyarakat dunia dan pendidikan merupakan salah satu hal yang berdampak besar karena adanya wabah tersebut. Sistem pembelajaran yang dilakukan secara tatap muka berubah menjadi pembelajaran jarak jauh dengan tujuan agar pandemi segera berakhir. Pembelajaran yang dilakukan secara jarak jauh memberikan pengaruh yang sangat signifikan terhadap siswa dan guru. Tidak ada pilihan yang lebih baik sekian melakukan pembelajaran secara jarak jauh agar Hujan merupakan satu bentuk presipitasi (setiap produk dari kondensasi uap air di atmosfer) yang berwujud cairan. Presipitasi sendiri dapat berwujud padat (misalnya salju dan hujan es) atau aerosol (embun dan kabut). hujan terbentuk apabila titik air yang terpisah jatuh ke bumi dari awan. Curah hujan merupakan ketinggian air hujan yang terkumpul dalam tempat yang datar, tidak menguap, tidak meresap, dan tidak mengalir (Winarso, 2000).

Dalam tiga tahun terakhir kondisi iklim di Kota Jambi mengalami kondisi cuaca yang tak menentu. Pada tahun 2015 Kota Jambi mengalami kondisi curah hujan yang sangat sedikit. Dampak dari kejadian ini adalah Kota Jambi mengalami kekeringan pada beberapa mata air dan terjadi kebakaran hutan di beberapa tempat, bahkan Kota Jambi mendapat kiriman asap akibat kebakaran hutan yang terjadi di Muaro Jambi dan Batanghari (Prihartono, Hery, 2015). Sementara itu, pada tahun yang sama Kota Jambi mengalami curah hujan yang tinggi. Oleh sebab itu, terjadi bencana alam seperti banjir yang menimbulkan kerugian materi (Nurdin, Dedy, 2015). Faktor umum yang mempengaruhi kondisi ini adalah perubahan iklim global yang dialami oleh Kota Jambi. Informasi yang berkaitan dengan kondisi di masa yang akan datang tidak dapat ditentukan secara pasti, tetapi bisa diprediksi. Dalam memprediksi suatu kejadian, terdapat metode yang mampu memprediksi kejadian di masa mendatang, yaitu dengan menggunakan analisis deret waktu. Analisis deret waktu digunakan untuk melakukan analisis data yang mempertimbangkan deret waktu. Data yang digunakan secara periodik berdasarkan urutan waktu bisa dalam hari, Minggu, bulan, dan tahun (Makridakis et all., 1999).

Salah satu cara memprediksi curah hujan dengan menggunakan pendekatan Filter Kalman. Namun dalam hal ini, perbaikan bias prediksi diimplementasikan pada hasil peramalan dari ARIMA (Autoregressive Integrated Moving Average) dikarenakan telah adanya data pengukuran dari BMKG Stasiun Klimatologi Muaro Jambi yang juga merupakan fungsi waktu dan akan digambarkan pola yang ada dengan menggunakan Analisis Deret Waktu (Time Series), karena pada umumnya data curah hujan merupakan data dengan satu variabel dan bersifat time series, baik itu harian, bulanan, ataupun tahunan. Data time series adalah data yang memiliki runtun waktu yang lebih dari satu tahun pada satu objek atau data yang dikumpulkan dari waktu ke waktu terhadap satu objek. Oleh sebab itu, metode atau model yang digunakan adalah metode analisis time series (Lexy Janzen Sinay, et.all, 2016).

Model ARIMA merupakan model peramalan analisis runtun waktu yang bertujuan untuk mencari pola data yang cocok dari sekelompok data dan memanfaatkan sepenuhnya data masa lalu dan data sekarang untuk menghasilkan peramalan jangka pendek yang akurat. Model ini dapat digunakan untuk semua tipe pola data dan dapat menghasilkan perhitungan yang baik apabila data runtun waktu yang digunakan bersifat dependent atau berhubungan satu sama lain secara statistik (Makridakis et all., 1999). Bentuk umum dari model ARIMA (p,d,q) adalah sebagai berikut:

$$
Z_{t}=\mu+\phi_{1} Z_{t-1}+\phi_{2} Z_{t-2}+\cdots+\phi_{p} Z_{t-p}+a_{t}-\theta_{1} a_{t-1}-a_{t}-\theta_{2} a_{t-2}-\cdots-a_{t}-\theta_{q} a_{t-q}
$$

Salah satu dari model peramalan yang dapat digunakan untuk melakukan suatu deret waktu adalah dengan model Filter Kalman. Filter Kalman adalah sebuah model bagian dari state space (ruang keadaan) yang dapat diterapkan dalam model peramalan. Model ini menggunakan teknik rekursif dalam mengintegrasikan data pengamatan terbaru ke model untuk mengoreksi prediksi sebelumnya dan melakukan prediksi selanjutnya secara optimal berdasarkan informasi di masa lalu maupun berdasarkan informasi data saat ini (Wei, 2006). 
Tujuan dari penelitian untuk memprediksi curah hujan Kota Jambi tahun 2018 dengan model Filter Kalman. Sebelumnya data curah hujan dibentuk ke dalam model ARIMA untuk mencari model terbaik ARIMA. Setelah didapat model terbaik ARIMA selanjutnya membentuk model FIlter Kalman. Setelah model Filter Kalman terbentuk, dilakukan peramalan pada data curah hujan perbulan di Kota Jambi untuk satu tahun kedepan yaitu tahun 2018.untuk melihat keakuratan hasil prediksi menggunakan MAPE (Mean Absolute Percentage Error) merupakan metode atau alat ukur untuk menghitung kesalahan dalam peramalan. Jika kesalahan semakin kecil maka hasil peramalan akan semakin mendekati tepat.

\section{METODE}

\section{Tempat dan Waktu}

Pengumpulan data dalam penelitian ini dilakukan di Stasiun Klimatologi Muaro Jambi. Fokus penelitian ini adalah untuk mengetahui implementasi metode filter kalman dalam memprediksi curah hujan yang diperoleh melalui model ARIMA di Kota Jambi pada Tahun 2018.

\section{Variabel}

Variabel dalam penelitian ini adalah data curah hujan Kota Jambi dari Tahun 2008 sampai dengan Tahun 2017.

\section{Metode dan Analisis}

Teknik analisis data dalam penelitian ini yaitu data curah hujan dari tahun 2008 sampai dengan Tahun 2017 sebagai data training akan diidentifikasi dengan model ARIMA (p,d,q) untuk pembentukan model state space dan akan dilakukan prediksi curah hujan Kota Jambi tahun 2018 dengan metode Filter Kalman. Adapun tahapan analisis data yang dilakukan yaitu:

1. Identifikasi model ARIMA meliputi:

a. Melakukan analisis stasioneritas dalam rata-rata dan variansi.

b. Melakukan penetapan model sementara berdasarkan grafik ACF dan PACF.

2. Melakukan penaksiran parameter model ARIMA.

3. Melakukan uji diagnostik meliputi uji signifikansi parameter dan uji kesesuaian model (uji asumsi white noise dan uji kenormalan residual).

4. Pengukuran ketetapan model ARIMA.

5. Konstruksi model state space berdasarkan model ARIMA yang diperoleh.
a. Persamaan state.

b. Persamaan output.

6. Perhitungan persamaan rekursif FIlter Kalman.

7. Melakukan diagnostik model state space yang meliputi uji asumsi white noise dan uji kenormalan residual berdasarkan data yang sudah dikoreksi atau diperbaharui.

8. Melakukan prediksi curah hujan Kota Jambi tahun 2018 dengan metode Filter Kalman.

\section{HASIL DAN PEMBAHASAN}

Data yang digunakan merupakan data sekunder berupa data curah hujan dalam bentuk bulanan yang didapatkan dari Stasiun Klimatologi Muaro Jambi dan data mengambil data curah hujan dari tahun 2008 sampai dengan tahun 2017 yang dinyatakan dalam mm (milimeter).

Tabel 1. Data Curah Hujan 2008 Sampai 2017 (mm)

\begin{tabular}{|c|c|c|c|c|c|c|c|c|c|c|c|c|}
\hline TAHUN & JAN & FEB & MAR & APR & MEI & JUN & JUL & AGT & SEP & OKT & NOV & DES \\
\hline 2008 & 185.3 & 98.3 & 331.2 & 258.2 & 82.3 & 26.8 & 69.1 & 245.4 & 107.1 & 204.0 & 317.5 & 325.0 \\
\hline 2009 & 118.3 & 342.1 & 193.8 & 177.2 & 122.4 & 117.1 & 60.2 & 154.6 & 162.5 & 171.3 & 345.0 & 336.0 \\
\hline 2010 & 111.9 & 290.2 & 204.1 & 219.7 & 279.1 & 167.8 & 389.0 & 345.8 & 262.3 & 372.8 & 333.8 & 230.0 \\
\hline 2011 & 313.0 & 173.5 & 226.5 & 267.8 & 119.4 & 93.7 & 144.1 & 29.5 & 36.3 & 211.4 & 285.8 & 180.3 \\
\hline 2012 & 135.5 & 130.2 & 222.4 & 244.4 & 266.1 & 52.7 & 108.0 & 54.5 & 52.8 & 276.9 & 149.9 & 225.2 \\
\hline
\end{tabular}


https://journal.neolectura.com/index.php/nucleus

\begin{tabular}{lllllllllllll}
2013 & 150.1 & 176.6 & 326.0 & 125.1 & 182.8 & 83.0 & 209.1 & 73.4 & 235.4 & 325.3 & 170.7 & 296.0 \\
2014 & 91.9 & 26.2 & 101.0 & 338.1 & 108.9 & 102.1 & 195.1 & 184.7 & 67.0 & 100.6 & 228.0 & 253.9 \\
2015 & 158.1 & 111.4 & 178.1 & 303.5 & 134.2 & 34.6 & 73.1 & 37.4 & 10.0 & 36.0 & 345.2 & 299.0 \\
2016 & 103.8 & 207.3 & 70.1 & 233.6 & 80.3 & 76.1 & 127.1 & 199.3 & 109.4 & 130.2 & 209.4 & 140.0 \\
2017 & 128.0 & 191.0 & 198.0 & 301.0 & 155.0 & 163.0 & 54.0 & 68.0 & 217.0 & 231.0 & 342.0 & 273.0 \\
\hline
\end{tabular}

Sumber: Stasiun Klimatologi Muaro Jambi

\section{Pembentukan Model ARIMA}

\section{Identifikasi Model}

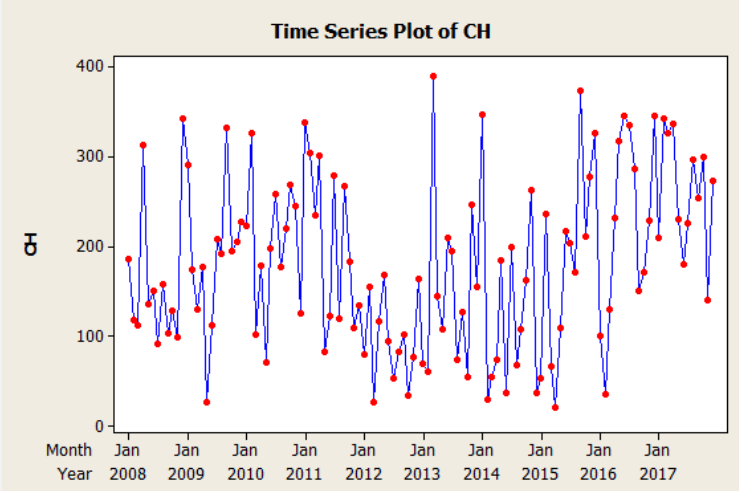

Gambar 1. Time Series Plot Curah Hujan

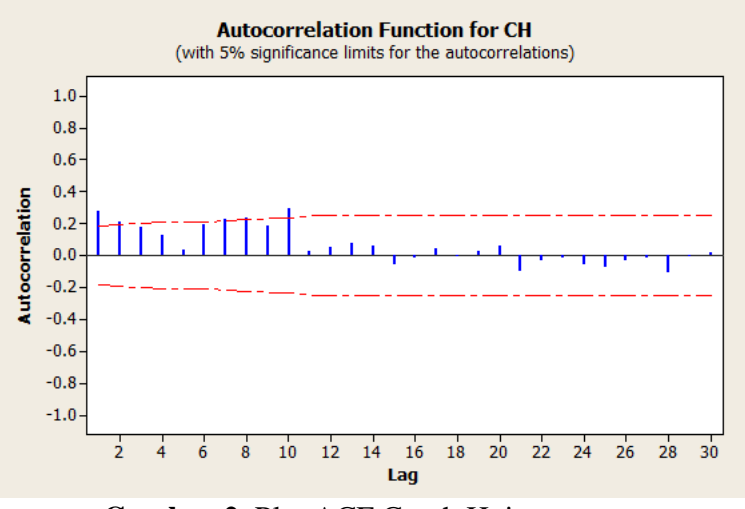

Gambar 2. Plot ACF Curah Hujan

Gambar 1 menunjukkan bahwa curah hujan di Kota Jambi secara visual belum stasioner karena fluktuasi data tidak berada pada nilai rata-rata yang konstan. Berdasarkan plot ACF pada gambar 2 tersebut juga diidentifikasi bahwa data tidak memiliki pola musiman.

\section{Identifikasi Stasioner Time Series}

Setelah mengidentifikasi pola dan karakteristik data, langkah selanjutnya dilakukan analisis dengan melihat plot Box-Cox untuk melihat apakah data curah hujan sudah stasioner terhadap varians.

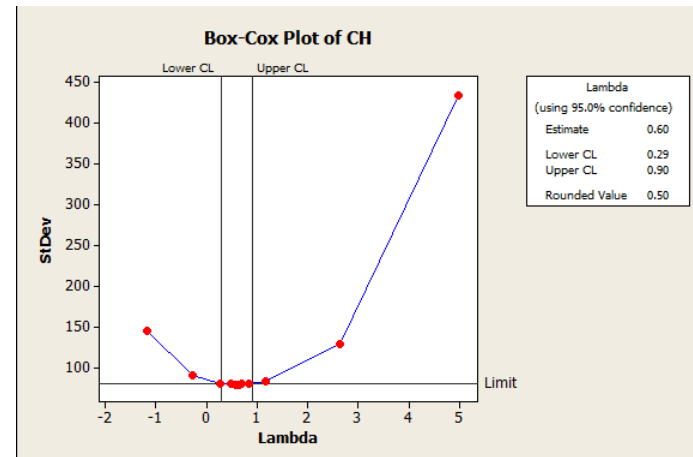

Gambar 3. Box-Cox Plot Curah Hujan di Kota Jambi

Gambar 3 diketahui bahwa data curah hujan di Kota Jambi belum stasioner terhadap varians. Hal ini ditunjukkan dengan nilai Lower $C L$ dan Upper $C L$ yang belum melewati angka 1 atau bisa juga dilihat pada nilai rounded value $(\lambda)$ yang belum bernilai satu. Karena nilai $\lambda$ sebesar 0.5 maka data akan ditransformasikan $\sqrt{Y_{t}}$ untuk menstabilkan varians. 


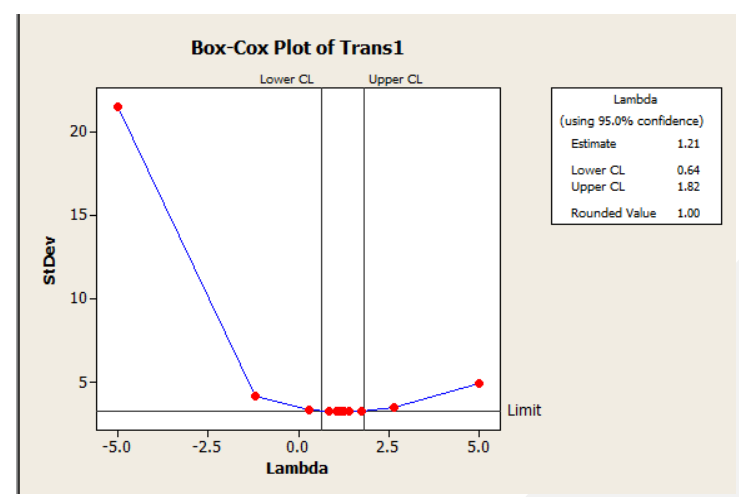

Gambar 4. Box-Cox Data Curah Hujan di Kota Jambi Hasil Transformasi

Setelah dilakukan transformasi maka dilakukan analisis Box-Cox kembali untuk mengetahui apakah data sudah stasioner terhadap varians atau belum. Gambar 4 merupakan BoxCox curah hujan yang telah dilakukan transformasi. Dapat dilihat bahwa nilai Lowe CL dan Upper $C L$ yang sudah melewati angka 1 dan nilai rounded value $(\lambda)$ yang bernilai satu, sehingga data hasil transformasi sudah stasioner terhadap varians.

Setelah stasioneritas data terhadap varians terpenuhi, maka selanjutnya dilakukan pengujian stasioneritas data terhadap mean dengan melihat plot ACF dari hasil transformasi. Gambar 5 menunjukkan bahwa plot berfluktuasi di sekitar garis mean dan tidak lebih dari tiga lag awal melewati garis mean.

\section{Identifikasi Model ARIMA}

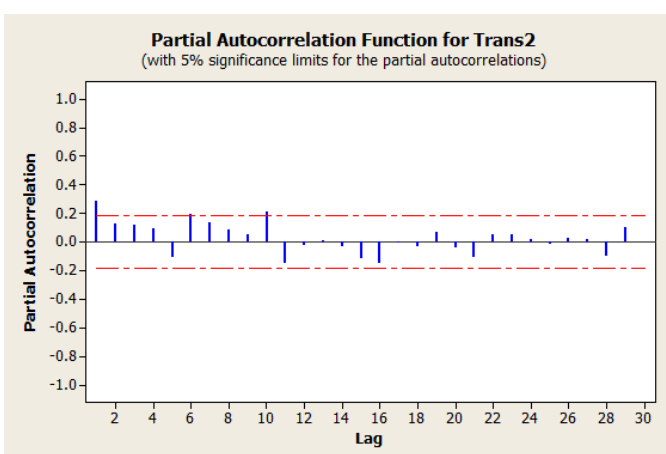

Gambar 6. Plot PACF Hasil Transformasi

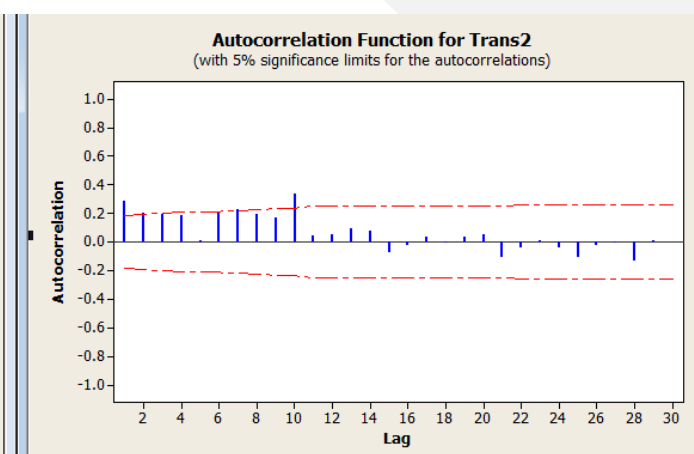

Gambar 7. Plot ACF Hasil Transformasi

Setelah data hasil transformasi sudah stasioner terhadap varians dan mean maka selanjutnya dilakukan identifikasi model ARIMA sementara berdasarkan pada plot ACF dan plot PACF data hasil transformasi sebagai berikut.

Pada plot ACF (Gambar 7) menunjukkan bahwa plot ACF memiliki pola dying down, sedangkan plot PACF (Gambar 6) memiliki pola dying down yang berarti taksiran orde AR pada nilai 1 dan orde MA pada nilai 1,2,3. Sehingga dugaan model yang digunakan adalah model ARIMA(1,0,1), model ARIMA(1,0,2), model ARIMA(1,0,3).

\section{Estimasi dan Pengujian Signifikansi Parameter}

Setelah mendapatkan model dugaan ARIMA, selanjutnya dilakukan estimasi parameter dan pengujian signifikansi parameter pada masing-masing model ARIMA dinyatakan dengan Hipotesis sebagai berikut.

$\mathrm{H}_{0}: \square \Phi=0$ (parameter model tidak signifikan)

$\mathrm{H}_{1}: \square \Phi \neq 0$ (parameter model signifikan)

Di mana $\Phi$ adalah parameter pada model ARIMA, dengan taraf signifikan $\alpha$ sebesar $5 \%$. Tolak $\mathrm{H}_{0} \mathrm{jika}|\mathrm{t}| \geq \mathrm{t}(\alpha, n-1)$. hasil estimasi dan pengujian parameter adalah sebagai berikut. 
Tabel 2. Estimasi dan Pengujian Signifikansi Parameter

\begin{tabular}{llllll}
\hline Model Dugaan & Parameter & $\mid$ thitung & $t_{\text {tabel }}$ & $P$-value & Keputusan \\
\hline \multirow{2}{*}{ ARIMA(1,0,1) } & $\phi_{1}$ & 12.81 & 1.66 & 0.00 & Signifikan \\
& $\theta_{1}$ & 6.71 & 1.66 & 0.00 & Signifikan \\
& $\phi_{1}$ & 11.75 & 1.66 & 0.00 & Signifikan \\
ARIMA(1,0,2) & $\theta_{1}$ & 5.86 & 1.66 & 0.00 & Signifikan \\
& $\theta_{2}$ & 0.71 & 1.66 & 0.482 & Tidak Sig \\
& $\phi_{1}$ & -2.52 & 1.66 & 0.013 & Signifikan \\
& $\theta_{1}$ & -2.98 & 1.66 & 0.003 & Signifikan \\
& $\theta_{2}$ & -1.73 & 1.66 & 0.087 & Signifikan \\
& $\theta_{3}$ & -0.14 & 1.66 & 0.888 & Tidak Sig \\
\hline
\end{tabular}

Berdasarkan Tabel 2 dapat dilihat bahwa parameter pada model ARMA(1,0,1) dugaan, signifikan karena nilai absolut $t$ lebih besar dari nilai $t_{\text {tabel }}$. Maka model $\operatorname{ARMA}(1,0,1)$ dapat digunakan.

\section{Pengujian Asumsi Residual}

Setelah mendapatkan model dugaan yang signifikan, selanjutnya dilakukan pemeriksaan terhadap residualnya. Asumsi yang harus dipenuhi yaitu white noise dan berdistribusi normal. Pemeriksaan asumsi white noise menggunakan uji Ljung-Box, sedangkan asumsi berdistribusi normal menggunakan Kolmogorov-Smirnov. Pemeriksaan asumsi white noise dengan menggunakan uji Ljung-Box dengan hipotesis sebagai berikut.

$\mathrm{H}_{0}: \rho_{12}=\rho_{24}=\rho_{36}=\rho_{48}=0$ (Residual data curah hujan kota Jambi memenuhi syarat white noise) $\mathrm{H}_{1}$ : Minimal ada satu $\rho \mathrm{k}$, untuk $\mathrm{k}=12,24,36,48$ (Residual data curah hujan kota Jambi tidak memenuhi syarat white noise)

Dengan taraf signifikan $\alpha$ sebesar $5 \%$ dan $\mathrm{H}_{0}$ ditolak jika $x_{\text {hitung }}^{2}>x_{\alpha ; d f}^{2}$ atau p-value $<\alpha$. Hasil uji Ljung-Box pada masing-masing variabel akan ditampilkan pada tabel berikut.

Tabel 3. Hasil Uji Ljung-Box Pada Model ARIMA yang Telah Signifikan

\begin{tabular}{lcccccc}
\hline Model Dugaan & Lag & $\chi^{2}$ & DF & $\chi^{2}$ tabel & P-value & Keputusan \\
\hline \multirow{2}{*}{ ARIMA(1,0,1) } & 12 & 20.3 & 9 & 16.92 & 0.016 & Hoditolak \\
& 24 & 28.5 & 21 & 33.67 & 0.126 & $\mathrm{H}_{0}$ diterima \\
& 36 & 42.0 & 33 & 47.40 & 0.135 & $\mathrm{H}_{0}$ diterima \\
& 48 & 48.3 & 45 & 61.66 & 0.341 & $\mathrm{H}_{0}$ diterima \\
ARIMA(1,0,2) & 12 & 20.0 & 8 & 16.92 & 0.010 & $\mathrm{H}_{0}$ ditolak \\
& 24 & 28.1 & 20 & 33.67 & 0.108 & $\mathrm{H}_{0}$ diterima \\
& 36 & 41.5 & 32 & 47.40 & 0.121 & $\mathrm{H}_{0}$ diterima \\
& 48 & 48.2 & 44 & 61.66 & 0.308 & $\mathrm{H}_{0}$ diterima \\
& 12 & 27.9 & 7 & 14.07 & 0.000 & $\mathrm{H}_{0}$ ditolak \\
& 24 & 36.1 & 19 & 30.14 & 0.010 & $\mathrm{H}_{0}$ diterima \\
& 36 & 53.9 & 31 & 44.99 & 0.007 & $\mathrm{H}_{0}$ diterima \\
& 48 & 65.4 & 43 & 59.30 & 0.015 & $\mathrm{H}_{0}$ diterima \\
\hline
\end{tabular}

Berdasarkan Tabel 3 didapatkan ketiga model memenuhi asumsi white noise, sehingga kedua model tersebut dapat digunakan. Selanjutnya dilakukan pengujian asumsi residual berdistribusi normal dengan uji Kolmogorov-Smirnov dengan hipotesis sebagai berikut. 
$\mathrm{H}_{0}$ : Residual data curah hujan kota Jambi berdistribusi normal

$\mathrm{H}_{1}$ : Residual data curah hujan kota Jambi tidak berdistribusi normal

Dengan taraf signifikan $\alpha$ sebesar $5 \%$ dan $\mathrm{H}_{0}$ ditolak jika $\mathrm{KS}_{\text {hitung }}>\mathrm{KS}_{\text {tabel, }}$, atau p-value $<$ $\alpha$. Hasil pengujian asumsi residual berdistribusi normal dengan uji Kolmogorov-Smirnov adalah sebagai berikut.

Tabel 4. Uji Asumsi Residual Berdistribusi Normal

\begin{tabular}{|c|c|c|c|}
\hline \multirow{2}{*}{ Model Dugaan } & \multicolumn{2}{|c|}{ Kolmogorov-Smirnov } & \multirow{2}{*}{ Keputusan } \\
\hline & Nilai & Tabel & \\
\hline $\operatorname{ARIMA}(1,0,1)$ & 0.047 & 0.130 & Berdistribusi Normal \\
\hline $\operatorname{ARIMA}(1,0,2)$ & 0.048 & 0.130 & Berdistribusi Normal \\
\hline $\operatorname{ARIMA}(1,0,3)$ & 0.052 & 0.130 & Berdistribusi Normal \\
\hline
\end{tabular}

Berdasarkan Tabel 4 dapat dilihat bahwa pada semua model didapatkan nilai Kolmogorov-Smirnov lebih kecil dari nilai tabelnya, sehingga dapat disimpulkan bahwa residual data telah berdistribusi normal.

\section{Pemilihan Model Terbaik}

Setelah mendapatkan beberapa model dugaan yang telah signifikan dan memenuhi asumsi, maka selanjutnya dilakukan pemilihan model terbaik. Pemilihan model terbaik digunakan untuk mendapatkan model yang paling akurat di antara model-model lainnya.

Tabel 5. Nilai MSE

\begin{tabular}{ll}
\hline Model Dugaan & MSE \\
\hline ARIMA(1,0,1) & 12.56 \\
ARIMA $(1,0,2)$ & 12.60 \\
ARIMA $(1,0,3)$ & 13.18 \\
\hline
\end{tabular}

Berdasarkan pada Tabel 5 menunjukkan model ARMA([1,1]) memiliki nilai MSE lebih kecil dibanding model ARIMA $(1,0,2)$ dan model ARMA(1,0,2), maka model ARIMA terbaik untuk data curah hujan kota Jambi tahun 2008 - 2017 adalah model ARIMA $(1,0,1)$ dengan persamaan modelnya adalah :

$$
\mathrm{Z}_{\mathrm{t}}=0.8648+0.9335 \mathrm{Z}_{\mathrm{t}-1}-0,7874 \mathrm{a}_{\mathrm{t}-1}+\mathrm{a}_{\mathrm{t}}
$$

Setelah didapat persamaan model ARIMA terbaik, langkah selanjutnya dilakukan pemodelan Filter Kalman dari model ARIMA yang telah diperoleh.

\section{Pemodelan Filter Kalman}

Setelah didapat model ARIMA terbaik yaitu model ARIMA $(1,0,1)$. Selanjutnya data curah hujan dibagi menjadi dua yaitu data curah hujan waktu sebelumnya $\left(\mathrm{Z}_{\mathrm{t}-1}\right)$ dan data curah hujan waktu sekarang $\left(Z_{t}\right)$, diterapkan pada model state space maka akan menjadi $Z_{t}=\left[\begin{array}{c}Z_{t-1} \\ Z_{t}\end{array}\right]$. Model state space direpresentasikan dalam bentuk persamaan state transition dan persamaan output yaitu:

$$
\begin{gathered}
\bar{Z}_{t+1}=F \bar{Z}_{t}+G \bar{a}_{t+1} \sim N(0, \Sigma) \\
\bar{X}_{t}=H \bar{Z}_{t}+\bar{b}_{t} \sim N(0, \Omega)
\end{gathered}
$$

Nilai parameter dari model state space berdasarkan model ARIMA $(1,0,1)$ adalah:

$\phi_{1}=0.9335, \boldsymbol{\theta}_{1}=0.7874 . \quad F=\left[\begin{array}{ll}\phi_{1} & 1 \\ \phi_{2} & 0\end{array}\right]=\left[\begin{array}{cc}0.9335 & 1 \\ 0 & 0\end{array}\right], G=\left[\begin{array}{ll}1 & \theta_{1}\end{array}\right]=\left[\begin{array}{ll}1 & 0.7874\end{array}\right]$, sedangkan matriks $\mathrm{H}, \Sigma, \Omega$ diasumsikan sebagai matriks $I$. Sehingga diperoleh persamaan state transition :

$$
\begin{aligned}
& \bar{Z}_{t+1}=F Z_{t}+G \bar{a}_{t+1} \\
& {\left[\begin{array}{c}
Z_{t+1} \\
Z_{t}
\end{array}\right]=\left[\begin{array}{cc}
0.9335 & 1 \\
0 & 0
\end{array}\right]\left[\begin{array}{c}
Z_{t-1} \\
Z_{t}
\end{array}\right]+\left[\begin{array}{ll}
1 & 0.7874
\end{array}\right]\left[\begin{array}{c}
a_{t+1} \\
a_{t}
\end{array}\right]}
\end{aligned}
$$


$\mathrm{Z}_{\mathrm{t}+1}=0.9335 \mathrm{Z}_{\mathrm{t}-1}+\mathrm{Z}_{\mathrm{t}}+\mathrm{a}_{\mathrm{t}+1}+0.7874 \mathrm{a}_{\mathrm{t}}$

$\mathrm{Zt}=\mathrm{a}_{\mathrm{t}+1}+0.9335 \mathrm{Z}_{\mathrm{t}-1}+0.7874 \mathrm{a}_{\mathrm{t}}$

Dan persamaan output :

$\bar{X}_{t+1}=H Z_{t}+b_{t}$

$\left[\begin{array}{c}X_{t-1} \\ X_{t}\end{array}\right]=\left[\begin{array}{ll}1 & 0 \\ 0 & 1\end{array}\right]\left[\begin{array}{c}Z_{t-1} \\ Z_{t}\end{array}\right]+\left[\begin{array}{c}b_{t-1} \\ b_{t}\end{array}\right]$

$\mathrm{X}_{\mathrm{t}-1}=\mathrm{Z}_{\mathrm{t}-1}+\mathrm{b}_{\mathrm{t}-1}$

$X_{t}=Z_{t}+b_{t}$

Setelah semua langkah pada pemodelan Filter Kalman dilakukan maka selanjutnya akan diprediksi curah hujan dengan Filter Kalman untuk 12 bulan ke depan.

Tabel 6. Hasil Ramalan Curah Hujan di Kota Jambi Tahun 2018 (mm)

\begin{tabular}{lc}
\hline Bulan & Hasil Prediksi \\
\hline Januari & 98.7 \\
Februari & 89.6 \\
Maret & 101.0 \\
April & 338.1 \\
Mei & 108.9 \\
Juni & 102.1 \\
Juli & 195.1 \\
Agustus & 184.7 \\
September & 79.4 \\
Oktober & 100.6 \\
November & 228.0 \\
Desember & 253.9 \\
\hline
\end{tabular}

Hasil perbandingan prediksi model Filter Kalman dan data aktual dapat dilihat pada gambar 8

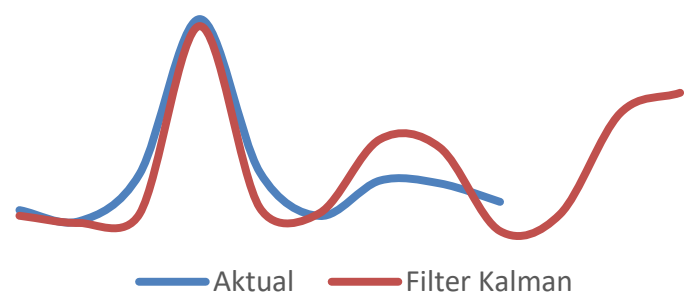

Gambar 8. Hasil Perbandingan Data Aktual dan Filter Kalman

Berdasarkan gambar 8 hasil perbandingan tersebut menunjukkan data aktual dan prediksi model Filter Kalman tidak terlalu jauh yang berarti hasil perbandingan tersebut baik. Dari hasil prediksi yang telah diperoleh maka dihitung nilai MAPE (Mean Absolute Precentage Error). Kemampuan peramalan sangat baik jika memiliki nilai MAPE kurang dari 10\%, mempunyai kemampuan peramalan baik jika memiliki nilai MAPE antara $10 \%$ dan 20\%, mempunyai kemampuan peramalan cukup baik jika memiliki nilai MAPE antara 20\% dan 50\%, dan kemampuan peramalan rendah jika memiliki nilai MAPE lebih dari 50\% (Gaspersz, 1998). Nilai MAPE dihitung dengan rumus sebagai berikut.

MAPE $=\frac{\sum_{t=1}^{n} \frac{\left|Z_{t}-\hat{Z}_{t}\right|}{Z_{t}}}{n} \times 100 \%=24.9 \%$ 
Maka diperoleh nilai MAPE dari prediksi Filter Kalman sebesar 24.9\% yang menunjukkan bahwa model tersebut mempunyai kemampuan prediksi yang cukup baik.

\section{PENUTUP}

Berdasarkan hasil pembahasan mengenai prediksi curah hujan Kota Jambi maka dapat disimpulkan:

1. Model ARIMA untuk data curah hujan Kota Jambi pada periode Januari 2008 sampai dengan Desember 2017 yang terbentuk adalah model ARIMA $(1,0,1)$ dengan persamaan modelnya adalah:

$$
Z_{t}=0.8648+0.9335 Z_{t-1}-0,7874 a_{t-1}+a_{t}
$$

2. Model state space untuk data curah hujan di Kota Jambi pada periode Januari 2008 sampai dengan Desember 2017 berdasarkan model ARIMA $(1,0,1)$ yang direpresentasikan dalam bentuk persamaan state transition dan persamaan output yaitu:

- Persamaan state transition :

$$
\begin{aligned}
& Z_{\mathrm{t}+1}=0.9335 \mathrm{Z}_{\mathrm{t}-1}+\mathrm{Z}_{\mathrm{t}}+\mathrm{a}_{\mathrm{t}+1}+0.7874 \mathrm{a}_{\mathrm{t}} \\
& \mathrm{Zt}=\mathrm{a}_{\mathrm{t}+1}+0.9335 \mathrm{Z}_{\mathrm{t}-1}+0.7874 \mathrm{a}_{\mathrm{t}}
\end{aligned}
$$

- Persamaan output :

$$
\begin{aligned}
& X_{t-1}=Z_{t-1}+b_{t-1} \\
& X_{t}=Z_{t}+b_{t}
\end{aligned}
$$

3. Hasil perbandingan data aktual dalam Filter Kalman terlihat bahwa Filter Kalman mendekati data aktual dan diperoleh nilai MAPE sebesar 24.9\% yang menunjukkan bahwa model Filter Kalman mempunyai kemampuan prediksi yang cukup baik.

Tingkat akurasi hasil ramalan curah hujan ini masih perlu dikembangkan dengan penelitian lebih lanjut, seperti modifikasi model yang diharapkan lebih sesuai dengan memasukkan juga variabel faktor yang mempengaruhi curah hujan dan menggunakan metode yang lain untuk membandingkan hasil ramalan tersebut.

\section{DAFTAR PUSTAKA}

Gaspersz, V. (1998). Production Planning and Inventory Control. Jakarta: Gramedia Pustaka Utama.

Janzen, S. L. Dkk. (2016). Analisis Model Curah Hujan di Kota Ambon Menggunakan Metode Box-Jenkins. Pengembangan Penelitian Pendidikan Matematika Untuk Mendukung Peningkatan Kualitas Pembelajaran Matematika. Ambon: Universitas Pattimura.

Makridakis, S., Wheelwright, S. C., dan McGee, V. E. (1999). Metode Dan Aplikasi Peramalan. Diterjemahkan oleh U. S. Adriyanto, dan A. Basith. Jakarta: Airlangga.

Nurdin, D. (2015). Galeri Foto: Banjir Mulai Kepung Kota Jambi. http://jambi.tribunnews.com/2015/12/13/galeri-foto-banjir-mulai-kepung-kota-jambi. Diakses pada tanggal 9 Maret 2018.

Prihartono, H. (2015). Ini Sumber Kabut Asap yang Hari Ini Menyelimuti Kota Jambi. http://jambi.tribunnews.com/2015/09/25/ini-sumber-kabut-asap-yang-hari-inimenyelimuti-kota-jambi. Diakses pada tanggal 9 Maret 2018.

Wei, W.W.S. (2006). Time Series Analysis Univariate and Multivariate Methods Second Edition. Canada: Pearson Education Inc.

Winarso., P.A. (2000). Kondisi dan Masalah Penyusunan Prakiraan Cuaca dan Iklim dan Proyeksinya di Indonesia. Jakrta: Badan Meteorologi dan Geofisika. 